\title{
THE CORRELATION OF LINGUISTIC PATTERNING AND SOCIETAL STRUCTURES IN SYSTEMIC TYPOLOGY*
}

Keywords: systemic typology, complexification, simplification, analyticity, syntheticity

\begin{abstract}
The article discusses the premises of the systemic typology of Gennadij Prokop'evic Mel'nikov in comparison with the precepts of the sociolinguistic typology of Peter Trudgill. The author, in particular, looks into the correlation of linguistic patterning and societal structures as presented in the two theories, and offers a detailed synopsis of the societal factors and their valuables (external determinants) used in the respective disciplines. Detailed discussion of the societal factors as presented in the systemic and social typologies is offered. Major differences between their classifications in Mel'nikov and Trudgill are substantiated. Finally, based on the postulates of Mel'nikov's typology, the paper dwells on the concept of internal determinant or, the communicative scope which optimizes all the levels of language system, while co-varying types of social structures with types of linguistic patterning.
\end{abstract}

\section{Introduction}

This is the first article in a series of two studies which have long been inspired by the work of Gennadij Prokop'evič Mel'nikov (22.08.1928-21.02.200o), an original Russian thinker and scholar whom this author, as a graduate student, met in 1987 in Moscow. ${ }^{1}$ Having made groundbreaking contributions to the theory of systemology, general linguistics, linguistic typology, areal linguistics, and historical sociolinguistics,

* I would like to thank Peter Trudgill for his valuable comments on an earlier version of this paper as well as the participants in a session, entitled The Life, Growth and Death of Languages, at the International Congress of Linguists, 21-27 July 2013, Geneva, for their insightful queries. Needless to say, all the shortcomings in the proposed discussion are mine. 
Mel'nikov created in the early 1970 a new discipline, "systemic typology", whose precepts were based on the linguistic views of Wilhelm von Humboldt, Izmail Sreznevskij, Oleksander Potebnja, and Jan Niecisław Ignacy Baudouin de Courtenay. Though remained largely on the outskirts of mainstream linguistics, this theory has unexpectedly found continuation in parallel research of Peter Trudgill in the field of sociolinguistic typology, a discipline tested by Mel'nikov and his students as early as the 1980s-199os in Moscow (e.g. Polikarpov 1989).

This is my intention in the proposed studies to bridge the two theories and, primarily, familiarize the cohort of linguists with Mel'nikov's understanding of the correlation of linguistic patterning and societal structures. As the latest and decisive push for writing this paper, I must mention the recent book of Trudgill (2011, also 1992, 1996, 1997, 2010) which summarized his lifelong research on the interrelationships which might exist between societal type generally, on the one hand, and aspects of linguistic structure, on the other. ${ }^{2}$ The scholar's efforts have largely been focused on the question as to what extent it is possible to link the typology of language varieties to the typology of societies without falling back into the mistaken notions of "primitive" languages and "primitive" societies. Overall, Trudgill managed to create a sociolinguistically-informed typology that portends significance sufficient to warrant critical revision of its two pivotal concepts, simplification and complexification, especially in relation to language contact.

In his latest book, Trudgill (2011: 2, also 1997: 350) argued that societal factors can be strongly involved in determining or influencing the speed of linguistic change. Conversely, linguistic changes are likely to relate to specific social structures and their changes. This is why, for instance, "conservative" language varieties with a minimum of changes tend generally also to be those which are relatively more geographically isolated, and relatively more stable socially, than the more innovative language varieties which are found in contact (Trudgill 2011: 13-14). As a result, different rates and types of linguistic change can be related to (long-term) language contact, whence the well-known tendency toward, to use the "dynamic" term of Haspelmath and Michaelis (2017), "analyticization" in most of the Romance and Germanic languages, including the Scandinavian (Trudgill 1992: 195-197; Kusters 2003: 231-233, cf. Heine, Kuteva 2005: 32; Gil 2008: 110).

As has been declared, the main goal of my research is to critically review the aforementioned interpretation of linguistic change, primarily in the realm of morphosyntax. Leaving sound changes for future discussion, I argue that the advancement of "social determinants" of linguistic patterning (Trudgill 1997: 350) is not

As a graduate student in the Department of General and Russian Linguistics at the University of Peoples' Friendship (Russia, Moscow) in the years 1987-1990, this author had an opportunity of attending some lectures of Mel'nikov whose spontaneous talks and discussions right in the corridors of the university proved to be more inspirational than some of the meetings and classes scheduled in the department.

2 Interestingly enough, in his personal communication to this author, Trudgill stated that he had never heard about Mel'nikov and his scholarly output, thus eliminating any possible connection between the two scholars and their theories which, as I will show, have so much in common. 
sufficient for the explanation of the emergence of particular linguistic structures and of ensuing changes. I concur with Mel'nikov (2003: 137-141) that the societal factors and their variables, including language contact, play no i m mediat e role in the development and change of particular linguistic structures. This is why the major shortcoming of the sociolinguistic typology of Trudgill lies in the absence of what can be called an in te $\mathrm{r}$ a l d e te $\mathrm{rm}$ i $\mathrm{n}$ a $\mathrm{nt}$ which is a core element in the complexity metric for language development and change in the systemic typology of Mel'nikov (1973, 2003: 57, 91; Danylenko 2003: 361-366).

In this paper I discuss the corresponding notions in search of the lines of their possible interdependency, namely, society (societal factors) - language system - language change (whether contact-induced or internally motivated). I consider the societal factors that constitute the ex $\mathrm{te} r \mathrm{n}$ a $\mathrm{l}$ (societal) d e ter min a n t (a term used by both Mel'nikov and Trudgill) and, ultimately, shape the in ternal (linguistic) d e te r m i na n t (a term introduced by Mel'nikov) of a particular language tending either to accrue complexity or just simplify. Correspondingly, the discussion of societal factors will be conducted in Section 2, including some cases of the association of different linguistic types and linguistic structures with different types of societies (speech communities). The material for this paper is primarily Indo-European copiously discussed in Trudgill (2011), especially Slavic which is not, however, sufficiently represented in recent works dealing with the correlation of language patterning and societal structures (see Miestamo, Sinnemäki, Karlsson 2008; Sampson, Gil, Trudgill 2009; Trudgill 2011). Finally, in Sections 3-3.2, the necessity to consider a missing i n t e r m e d i a t e component (internal determinant) between the societal factors (external determinant) and the language system is substantiated. Conclusions are offered in Section 4.

\section{The external determinant(s)}

It is generally assumed that the distribution of linguistic patterns across the languages of the world may not be random. As Trudgill (2010: 300, 2011: 13-14) and some of his predecessors argued, major societal factors may include, but are not limited to, the following variables:

1. small versus large community size (also Haudricourt 1961);

2. dense versus loose social networks (Milroy, Milroy 1985);

3. social stability vs. instability of communities (Dixon 1997);

4. high versus low degree of shared background information (Martinet 1979);

5. degree of contact versus isolation.

Factor (5) seems to stand apart from the rest of the external determinants of speech community. Arguably, the low density of social networks with a small amount of shared background information and the low level of social stability of a particular community, are likely to be provoked by a high level of language contact. 
Conversely, a high level of (adult) language contact presupposes a loosening of social networks within an ever-growing community whose speakers are gradually losing amounts of shared background information due to the exponential increase of their number.

Another list of societal factors and their valuables was offered by Mel'nikov (1969, 1971, also 2003: 107, 138-141). They are summarily represented in Table 1.

Societal factor

\begin{tabular}{ll}
\hline 1 & The relative size of speech community \\
\hline 2 & The relative homogeneity of speech community \\
\hline $3 \quad \begin{array}{l}\text { Space and/or time constraints on communication } \\
\text { (distribution of speech acts in time and space) }\end{array}$ \\
\hline $\begin{array}{l}\text { The relative degree of heredity in transmitting lin- } \\
\text { guistic and cultural experience }\end{array}$
\end{tabular}

Variable

micro-community

macro-community

mega-community

homogeneous

heterogeneous

space and/or time constraints no constraints

a high degree of heredity

a low degree of heredity

Table 1. Societal factors and their variables, according to Mel'nikov

It is noteworthy that, unlike factor (5) in Trudgill's classification, language contact as a mere exponent of variables (2) and (4) is not included in Mel'nikov's system. For instance, the relative degree of homogeneity of speech community depends on the relative degree of contact versus isolation. Thus, the relative degree of heterogeneity tends to increase due to long-term contacts that presuppose active adult language learning.

According to Mel'nikov (2003: 210-116), space and time constraints are related to the sedentary or non-sedentary (migratory, nomadic) way of living of the members of speech community. To take a sedentary mega-community as an example, a speaker construes complex messages, permeated with redundant information and based on the inflecting technique, in order to update his interlocutor(s) on the events that took place during his/their absence. Additionally, for the sedentary type of macroand especially micro-community one can speak about the high degree of hereditary in transmitting linguistic and cultural experience. For a migratory community of the speakers of an agglutinative language, the hereditary degree of language and culture transmission tends to be lower in comparison with that in the community of speakers of an inflecting language. This is why, as Mel'nikov (2003: 121) argued, in the migratory type of speech community, communication is likely to be premised on the marshaling (agglutination) of regular and transparent elements in order to avoid their misinterpretation.

Rodionov (1989: 27-28) juxtaposed Mel'nikov's systemic typology with the holistic typology of ideal constructs created by Skalička (1966; see also Sgall 1971; Plank 1998). However, being objektbezogen, systematic typology, in addition to the 
portrayal of ideal types, seeks to ascertain the internal determinant of the inter-level interdependencies characterized by a particular patterning. In a sense, Plank (1998) advocated the same, holistic typology premised on the idea of interdependency of subsystems of language, although this typology has been progressing slower than any other typology because of its grander dimensions. ${ }^{3}$ Conceivably, the sociolinguistic typology of Trudgill also tends to become objektbezogen, looking into the co-variation of phonology with morphology and syntax, although with one principle difference. In Trudgill's sociolinguistic typology, the inter-level dependencies are directly influenced by societal factors and, as we will see below, appear separated from speakers.

One can find, nevertheless, many similarities between Mel'nikov's and Trudgill's approaches. Trudgill (2011: 147) believes that societal factors are not bipolar dyads but rather admit of very considerable degrees of more or less. He uses the label "small" as a kind of shorthand for "small, tightly-knit, isolated" and "large" as shorthand for "large, loosely-knit, high contact", although without bringing possible constellation of societal factors into line with certain typological configuration of language structures.

To give an example of a similar approach, Type 1 and Type 2 communities in Kusters (2003: 41-42, 2008: 14-15) are also potentially implicationally related to both Mel'nikov's systemic typology and Trudgill's sociolinguistic typology. Leaving certain details aside, Type 1 community is relatively small, and most people know each other. They share a large common background. Life circles are relatively predictable. Originality and innovation are not appreciated very much; in addition, there is a body of literature (written or oral) in the community, which has a sacrosanct status. Different registers exist, which are largely shared by the members of the community. Importantly, ties between community members are strong. An instantiation of this idealized Type 1 community, according to Kusters (2003: 42), is the Shammar community in northern Saudi Arabia, who speaks a form of Nadji Arabic. The latter emerged as a result of contact of a dramatic type that followed on from the expansion of Arabic out of the Arabian Peninsula (see Trudgill 2011: 45).

Type 2 communities only form a speech community because all members use the same language (Kusters 2003: 42). They do not necessarily form a unit in space or time, or share other social or cultural values, and their precise way of speaking the language in question may differ. Additionally, this language is not associated with any cultural or religious standard. There are either no different registers, but there may be different dialects. In order to be understood by outsiders, the speakers of

\footnotetext{
The holistic typology has become relatively popular in western European scholarship after the publication of programmatic articles by Plank $(1986,1998)$. However, neither Plank nor the adherents of his holistic (systemic) approach (e.g., Fenk-Oczlon, Fenk 1999, 2008) have ever mentioned Mel'nikov's or his followers' works (e.g. Zubkova 1977, 1990, 2010). Moreover, Mel'nikov's first book on systemology, Systemology and linguistic aspects of cybernetics, translated into English and published in Amsterdam in 1988, has remained unknown to most of the generalists (Mel'nikov 1988b); for a rare discussion of Mel'nikov's systemic typology, in particular of his posthumously published doctoral habilitation dissertation, see Tambovtsev (2005).
} 
such a community must accommodate and assimilate each of their ways of speech. A prototypical example of a Type 2 community is the group of pidgin Swahili speakers in the larger cities in Kenya (Kusters 2003: 42).

As one can see, prototypical communities in the theory of Kusters, as well as in the sociolinguistic typology of Trudgill, tend to generate a number of societal "shades" thus corresponding with a variety of linguistic patterns. Mel'nikov (1986) posited only four typological constructs whose linguistic configurations remind, at first blush, the traditional morphological types of languages. However, according to Mel'nikov, they should be conceived dynamically, viz. as results of historical progression along the axis of syntheticity (from polysynthesis to flection) and the axis of analyticity (from isolation to agglutination) as determined by the corresponding societal variables. ${ }^{4}$ Thus, the synthetic constructs are typical of small and large speech communities, while the analytic constructs are used in intermediate (macro-)communities (Mel'nikov 1986: 24-25).

To apply Mel'nikov's logic to Russian as a highly inflecting language (see Danylenko 2013: 154), it has been historically spoken in an homogeneous sedentary mega-community (Sreznevskij 1887: 3-10), characterized by dense social networks and a high degree of heredity of linguistic and cultural experience (see Sinnemäki 2009: 129). Overall, the aforementioned societal variables create the most favourable milieu for the development of an inflecting system with a high level of syntheticity and fusion (Mel'nikov 2003: 117-118). At the same time, all other societal variables being equal, the macro-community of the speakers of Southwest Ukrainian, another Eastern Slavic dialect, demonstrates looser social networks due to relatively longterm language contact and other societal variables (Danylenko 2011: 147, 171-172). Hence a historical weakening of the "primary syntheticity" of its inflecting system, in particular in the fusion of inflected verb forms. To give an example, one can mention the preterite auxiliary clitics in Southwest Ukrainian. Unlike the Polish auxiliaries that turned into person-number markers (1a), the southwestern Ukrainian clitics are not fully degrammatized in this system. However, such clitics are altogether absent from North and Southeast Ukrainian (1c) as well as Russian which all are spoken within bigger but still homogeneous communities (see Danylenko 2012):
(1a) P byłem
be-pst.m.sg.=1sg.
(1b) SWU b̆yv jem
be-m.sg. pst.aux.1sg.
(1c) SEU buv
be-m.sg.
'I was.'

\footnotetext{
4 The direct relationship between, on the one hand, the term pair synthetic/analytic and, on the other, diachrony is postulated by Haspelmath and Michaelis (2017: 5) who argue that if we are dealing with a language whose history is totally unknown, we cannot classify its patterns as synthetic or analytic.
} 
Milroy and Milroy (1985:365-366) pointed out that smaller communities are likely to connect to each other and to a larger society through weak ties rather than strong ones. At the macro- and especially mega-level, societies (speech communities) undergoing processes which entail social and geographical mobility and the dissolution of closeknit networks provide the conditions under which innovations and corresponding changes can be rapidly transmitted along considerable social and geographical distances (Milroy, Milroy 1985:370). This scenario is applicable, for instance, in the case of English, French, Portuguese and some other Germanic and Romance languages that have diverged markedly from their ancestral forms. Unlike the more conservative type of Baltic and Slavic "pre-industrial" communities characterized by dense social networks, English, used in the industrial society with loose social networks, has changed radically since the 12th century while exhibiting gross dialectal variations (Millroy, Millroy 1985: 377; McWhorter 2008: 168; Trudgill 2011: 17-19). By contrast, Baltic and Slavic, in particular Lithuanian and Russian, whose respective speech communities have conserved, as has been mentioned, dense social networks, largely elaborated on the "Indo-European models" (Danylenko 2013: 153-156); hence the paradoxical profiling of Slavic as both conservative and innovative among all other Indo-European languages in Meillet (1924: 150-151).

In fact, Slavic is known to have retained and, especially in East Slavic, even further developed major verbal categories, including the categories of tense, aspect, and of the so-called procedurals (Andersen 2009: 125; Danylenko 2015). Called in Russian stepeni dlitel'nosti, the procedurals as derivational categories tended historically to change into the aspectual opposition, thus strengthening, according to Mel'nikov (1997: 130), the internal determinant of Slavic (see Sections 3.2 and 3.3). Thus Slavic reduced the number of aspectual distinctions down to the perfective vs. imperfective category, accompanied by a substantial simplification of tense forms and procedurals (Andersen 2006: 234-235; Danylenko 2013: 149-151).

Conceivably, the inventory of linguistic structures used in small close-knit communities looks different from that in languages spoken in large loosely-knit societies. It is not therefore surprising that the principle of economy tends to be associated with the notion of complexity vividly discussed in modern scholarship (Miestamo, Sinnemäki, Karlsson 2008; Sampson, Gil, Trudgill 2009). Martinet (1979) argued that in large communities understanding is better achieved if all grammatical relations are clearly marked and, it is worthwhile adding, redundant so that multiple interlocutors do not receive distorted messages, especially due to multiple contacts. In this respect, the situation is bound to be different in small communities with a minimum contact in which everybody knows what to expect from his neighbours (Tchekoff 1979: 409).

It would not therefore, it seems, be a mistake to suggest that the complexity of communicative tasks, determined by a specific configuration of societal variables, brings about a complexity of coding properties of grammatical relations (Mel'nikov 2003: 108-127). ${ }^{5}$ Among them one should name case marking, verb agreement/

Du Bois (1987: 843) who derived the morphological ergativity in Sacapultec Maya (spoken in highland Guatemala) from the principle of economy, argued that clearly accusative languages 
cross-reference, and other properties which naturally preclude speakers from relying on the cela-va-sans-dire-background typical of small communities (Tchekoff 1978: 44). However, some legitimate questions arise at this point. Is there then a cohesive link between the typology of speech communities characterized by particular configurations of the societal variables, on the one hand, and the typology of language varieties, on the other, as postulated by Trudgill? If such a link exists, how is it possible to have external variables influence immediately certain linguistic structures like the system of nominal classifiers or loss of case marking in Balkan Slavic (see Wahlström 2015: 135-136)?

Arguably, postulating an immediate influence of social motivations on language and its change is reminiscent of the separation of languages from speakers, partly, to use the words of Millroy and Millroy (1985:345), a hangover from the 19th-century insistence on the "life" of the language independent of speakers.

\section{The Internal Determinant}

There is no doubt that, despite the controversy of the Sapir-Whorf hypothesis and the class-character of Nikolaj Marr's Japhetidology as part of his "New Theory of Language" (Marr 1934), ${ }^{6}$ there is a connection of some sort between society and language. One can, in principle, agree with the existence of a certain parallelism between society and grammar as observed, for instance, in the influence of social change on verbal inflection (Kusters 2003).

However, the principle of parallelism is likely to prove fallacious in the long run (Section 3.1). An alternative reasoning is offered in Section 3.2. The particularities of the internal determinant in Slavic, on the one hand, and in the typologically innovative Western European languages, on the other hand, will be discussed in the next article dealing with the systemic typology of Mel'nikov.

such as English, German, French may realize, in spoken discourse with a relatively large amount active background information, an ergative grammatical structure. Conversely, solidly ergative languages, spoken in small, more loosely-knit communities with more shared background information may display a submerged pressure toward accusative patterning. As I will show in Sections 3.1, 3.3 and 4.3, the complexity of communicative tasks may be discourse-based only in the nominative-accusative languages since ergative grammar is a primary phase in the development of the nominative-accusative clause alignment (nominativity) along the axis of syntheticity. It also explains, according to Mel'nikov (2003: 125-127), historical drifts from nominativity back to ergativity in East Slavic due to a drastic decrease of the size of the corresponding homogeneous communities and some other changes in the external determinant (Danylenko 200o/1997: 62-64).

6 The views of Trudgill's followers who believe that linguistic patterns are dependent on sociolinguistic and even geographical settings (see Oksaar 1999; Sinnemäki 2009) are particularly vulnerable in this case. Both Marr's theory which has been recently declared as a historical reaction to the prevailing positivism in the early 20 th century (Alpatov 2006), and the postulates of modern sociolinguistic typology are seen as too mechanical, for they equate, in fact, socio-economic structures with linguistic patterns. In fact, unlike the tinge of dialectical materialism in the theory of Mel'nikov, Trudgill's sociolinguistic typology intrinsically accepts the aforementioned unidirectionality and the immediate influence of societal factors 


\section{1. "White-Box" Testing}

In one of his earlier publications, Kusters (2000) expressed a seemingly controversial view about the societal factors and different paths of simplification in Scandinavian and Quechua. He maintained, in particular, that societal factors, in particular language contact, do not suffice to explain the simplification in Continental Scandinavian because they do not explain why this process started before the contact period and still lasted until after this period (Kusters 2000: 227). Kusters argued therefore that these factors only accelerated the changes that were already on their way for independent reasons. Among those Kusters named a change in the prosodic system in Germanic. As a result of this change, inflecting endings began disappearing automatically. This scenario, according to Kusters (2000: 227-228), is corroborated by the fact that "all IE languages have simplified their inflections to a certain extent" - societal factors would then only boost a tendency that was already there.

Kuster's explanation seems to be less convincing than expected in the light of Mel'nikov's (2003: 116-120) line of argumentation. First, Scandinavian demonstrates a relatively high degree of fusion of its verbal and nominal inflection. This is why inflecting morphology, even in analytic English, is held to be one of the least borrowable parts of a language structure. If borrowed, it goes through a reinterpretation as agglutinative, cf. plural - $a$ in English words like criteri- $a$ from Latin plural nominative-vocative-accusative formative (Comrie 2008). Phonetic reduction, if any in such processes, is likely to play a secondary role. Second, Kuster trivialized the concept of societal factors, reducing them to language contact only, although the external influence on speakers is manifold and well structured (see Mel'nikov 1971; Trudgill 2010: 300-301). In fact, there should be a specific configuration (external determinant) of societal variables ready to initiate a change (Trudgill 1997: 350). In what one can concur with Kusters (2000: 229) is that differences between the ways of simplification in Scandinavian and Quechua may point, in addition to the external (societal) determinant, to the importance of the structure of the original language. Suffice it to say that Scandinavian is an inflecting system and Quechua, characterized by an advanced agglutinating technique (Cerrón-Palomino 1987: 280), can be viewed as a polysynthetic (incorporative) language with elements of active grammar, according to Mel'nikov (2003: 108-113; see Humboldt 1836: 277-278, 301). ${ }^{7}$ So the problem

on linguistic structures. As I show in Sections 3-3.4, the relationship between linguistic patterns and societal factors is secured through an intermediate component, the so-called "internal determinant" in the systemic typology of Mel'nikov (1971, 2003: 104-105).

7 One should not confuse the major technique with the principal feature, namely, the internal determinant, optimizing the whole system of a particular language as discussed in the systemic typology of Mel'nikov. Otherwise, one needs to deal with contradictory statements like those found in Adelaar's description of the grammar of Quechua. According to him, "Quechua is essentially agglutinative" and at the same time it is "a nominative-accusative language" (Adelaar 2004: 207), although the latter presupposes inflecting morphology with a pronounced tendency to fusion as observed in Slavic (Mel'nikov 2003: 118-120). Unlike inflecting languages, Quechua is characterized by a relatively high abstractness of most of its morphemes (Rodionov 1989: 28) which explains the abundance of morphological markers which play, as Adelaar (2004: 209) rightly assumed, a dominant role in this language. 
seems to reside in how we can reconcile the interaction, if any, between linguistic patterning and the respective societal factors, in particular language contact.

Before answering this question using the "black-box" testing, some additional comments are due here. Scholarly literature provides sufficient evidence to suggest that the speed of linguistic change in speech communities may depend on certain social changes either gradual or cataclysmic as postulated, for instance, in the punctuated equilibrium model by Dixon (1997: 67-85) or in a similar theory pioneered as early as 1850 by Sreznevskij (1887: 9-10). Contrary to Sreznevskij who postulated both gradual and moderately abrupt changes for Indo-European, and especially Slavic showing a high degree of the maturity of its features, ${ }^{8}$ Dixon suggested that during periods of rapid language change new categories tend to appear suddenly, for instance, the drift of ergative system to accusative system, but that such categories tend to be lost gradually. However, as Orr (1999: 135) pointed out in this respect, it is fairly easy to think of counterexamples. As an illustration, the category of verbal aspect can be reconstructed for Indo-European, and its development to the situation attested in Slavic can be seen, according to Orr, to have gradually evolved over several centuries. This change ran to its "logical" completion relatively abruptly in the 1300 s when a steep rise in the development of patterns of aspectual derivation became first attested (see Silina 1982). A (cyclic) drift of the accusative system back to ergativity is also possible since ergativity, according to Mel'nikov (1986: 23-24), is not so much a transitional stage from the active-type system to the nominativeaccusative grammar, but rather a primary phase in the development of the latter (see Bauer 2000: 43, 90-92). This may explain, for instance, why Indo-Iranian has only partly introduced a non-strict ergative construction in paraphrases with the ${ }^{*}$ ta- participles of transitive verbs co-existing with the accusative one (Harris, Campbell 1995: 244-245). Persuasive arguments for a similar but rather speedy drift from the nominative-accusative system to ergativity in some modern northern and western central Russian dialects were adduced in 1990 by one of Mel'nikov's graduate students (Lutin 1990; see Danylenko 2005: 368).

To tackle the question of both synchronic and diachronic correlation between the external determinant and linguistic patterning, one can resort to the black-box testing as applied in information technology. As Mel'nikov (2003: 69-73) reminded, in this testing a student examines the functionality of an application without peering into its internal structure. In particular, the student knows that a specific input (in our terms, external determinant) returns a certain output (lingu istic patterning) but is not aware of how the black box (language system) produces the output under consideration. A linguist must turn, according to Mel'nikov, to the so-called "white-box" testing, instead, while looking into internal structures

It should be reminded that Mel'nikov viewed Sreznevskij as one of the founding fathers of the systemic typology (Section 1). Interestingly enough, Plank (1998) and Fenk-Oczlon and Fenk (1999) chose for this purpose Georg von der Gabelenz who postulated inter-actions between sound structure and morphology and syntax. But his "systemic" vision was clearly narrower as compared with the conception of Wilhelm von Humboldt and his Slavic adaptors, including Sreznevskij (see Zubkova 1989). 
of an application. In this type of testing, an internal perspective of the system should be focused on a structural principle (located inside the "white" box) which, in accord with the input, determines the appropriate output or a specific linguistic patterning. In other words, in addition to the external determinant(s) of linguistic patterning propounded by Trudgill (1996: 350), a linguist should also ascertain the internal determinant of linguistic patterning. ${ }^{9}$

As the "white-box" testing analogy shows, one can hardly speak of an i m m e$\mathrm{d}$ iate $\mathrm{link}$ between the typology of speech communities and the typology of language patterning. The only way of substantiating a link between speech communities and language patterning lies, as has been mentioned, in searching for the internal determinant or, the "communicative scope" (Mel'nikov 1988a, 2003: 105-108; see Danylenko 2003: 347-366). The latter instantiates a principal feature optimizing, in harmony with the external determinant, all the levels of language system (Mel'nikov 2003: 57). Consequently, the systematic co-variation is found not only within levels or modules of grammar but also between them (Plank 1998; Zubkova 2010: 444-445). ${ }^{10}$

\subsection{Slavic aspect}

One of the exponents of the internal determinant as reconstructed for Indo-European is its verbal morphology (Meillet 1922), especially the tense and aspect system in Slavic in comparison with the analytic Western European languages that fall under the umbrella term "Standard Average European" (see Heine, Kuteva 2006: 4-10). Elsewhere I adduced arguments against a bias in the areal profiling of European languages and why Russian as "Standard Average Indo-European" might be placed at the centre of Europe as a linguistic area (Danylenko 2013: 153-156). As was noted

9 The concept of “internal determinant" in Mel'nikov's (1971, 1973, 2003: 69-70, 91, 93, 105) systemic typology bears a resemblance to the notion of the "character of language" ("der Character der Sprachen") in Humboldt (1836: 190-193) who deemed it more subtle, more deeply hidden and less accessible to analysis than the "grammatical structure" of language. Thus, to grasp the character of language, according to Humboldt and Mel'nikov, one should look into the internal course of linguistic development evolving under particular external circumstances.

10 Among the "co-variated" elements one can name phonological features configured in a peculiar way (fission) in classical Arabic. For instance, vowels $u, i$, and $a$ tend to render primarily nominal declensions and vowels $u, a$, and zero (sukut) are used in verbal conjugation (Kjamilev, Mel'nikov 1983: 92). At the same time, the vowel patterns of the augmented forms for the perfect stem are (a)- $a$ - $a$, while in the passive voice of the imperfect stem the vowel pattern is $u-a-(a)-(a)$ (see Wright 1967: 63-71; Kusters 2003: 29-30; Bohas 2006). In isolating Vietnamese in the syllable structure $\mathrm{C}_{1} \mathrm{VC}_{2}$ consonants show a clear contrast in three oppositions which are (1) [+ peripheral] vs. [+ medial], (2) [+ plosive] vs. [+ fricative], (3) [+ obstruent] vs. [+ sonorant]. As Zubkova (2010: 566) noted, in inflecting Russian, although somewhat slackened, a similar contrast found in the same syllable structure is premised primarily on the opposition [+ peripheral] vs. [+ medial]; the contrast of consonants in the same syllable in agglutinating Turkish is realized through the opposition [+ anterior] vs. [+ back]; for crosslinguistic correlations between the size of syllables, words, and sentences as confirmed in a wider sample of 18 Indo-European and 16 non-Indo-European languages, although without any reference to the external determinant, see Fenk-Oczlon and Fenk (1999). 
by Meillet, in particular, Russian together with most of the eastern Slavic dialects fully elaborated on prehistoric aspectual distinctions. With verbs of motion, in particular, Russian distinguishes not only between imperfectives and perfectives as this language does with almost all verbs, but makes a further subdivision within the imperfective of what grammarians have called "determinate" vs. "indeterminate", expressed with a separate root (Meillet 1924: 240-241):

(2) imperfective

'to go on foot'

'to go by a vehicle' / 'to ride a horse'

$\begin{array}{ll}\text { determinate } & \text { indeterminate } \\ \mathrm{R} \text { idti } & \mathrm{R} \text { xodit' } \\ \mathrm{R} \text { exat' } & \mathrm{R} \text { ezdit' }\end{array}$

If one adds here the procedural category the complexity of this subset of grammar looks even more complicated. ${ }^{11}$ Unlike aspects, which are obligatory grammatical categories, the procedurals are optional, derivational categories that modify the meaning of a lexical verb (see Maslov 1948). Historically, the category of procedural antedated the formation of the full-fledged category of aspect approximately in the 14th century, while becoming ultimately integrated into its binary system, whence the derivational irregularity of procedurals which in Russian, as Mel'nikov (1997: 136-137) demonstrated, fall into 5 classes (Potebnja 1941: 46-62; Danylenko 2003: 335-339). Among the imperfective indeterminates, one can cite the Russian multiplicative xaživat' 'to walk around', characterized by root vowel apophony and the procedural suffix -iva'-. Numerous prefixed procedurals, with lexical attenuations depending on the "spatial meaning" of preverbs, derive from this base multiplicative, whose use in the present tense has been taken over by po-xaživat' 'to walk around' with the semantically bleached prefix po- (Danylenko 2015: 536-537):

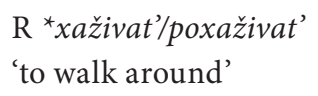

The category of aspect and the category of procedural, which is still operative in Slavic and in Baltic, are not found in other modern Indo-European languages (Danylenko 2003: 335-338, 2015: 533-539). As a result of the elaboration-through-simplification of aspectual oppositions, Slavic, especially Russian, acquired a three-tense system which is at variance with the extended tense system in the analytic Romance and Germanic languages. At the same time, accompanied by a substantial simplification of tense forms from seven to three, synthetic (East) Slavic reduced the number of aspectual distinctions down to the perfective vs. imperfective category combined with the category of procedural (cf. Danylenko 2013: 149-150).

All the above changes lead to the strengthening of the prospective "communicative scope" which in Slavic is derivative from the initial Indo-European ego-et-nunc

11 Surprisingly, having mentioned four kinds of past tense in Kikongo, a creole language used in Central Africa, McWhorter (2001: 127-128) juxtaposed this complexity with allegedly a similar complexity in the same "subset of grammar" in Russian. 
communicative scope. This notion is introduced in the second article dealing with the systemic typology of Mel'nikov. I discuss in particular two types of this scope as developed in Slavic, on the one hand, and in Germanic and Romance, on the other. In addition, I summarize major types of changes in the internal determinant (communicative scope) of an inflecting language system together with the respective societal valuables.

\section{Coda}

As I tried to show, there is much in common between the systematic typology of Mel'nikov who made pioneering contributions to linguistic studies and the sociolinguistic typology of Trudgill, whose theory is concerned with language change, contact, and search for complexity metrics. Unlike Trudgill who posits a direct covariation between social structures and linguistic patterns, Mel'nikov introduced a missing chain in the social typology of Trudgill, to wit, an internal determinant. In fact, the explanatory potential of Mel'nikov's typology is more pronounced than that in Trudgill. The systemic typology of Mel'nikov looks into configurations of the societal factors and their variables as well as their influence on the internal determinant as the principal feature optimizing the system of a particular language. This is why, though absent from the sociolinguistic typology of Trudgill, the internal determinant needs to be restored in analyzing the co-variation of linguistic and societal structures. Disregarding the internal determinant, which "mediates" between types of social structures with types of linguistic patterning, makes the position of Trudgill heuristically shaky as compared with that of Mel'nikov and his followers. This also can explain why both analytic and synthetic changes in Romance are viewed by some scholars as accidental and random (see Schwegler 1990: 185).

What is left to determine, is how the internal determinant changes and what factors can influence this process. The next article in the series of studies dealing with the theory of Mel'nikov is designed to tackle this query.

\section{Abbreviations}

AUX = auxiliary; $\mathrm{M}$ = masculine; $\mathrm{P}$ = Polish; $\mathrm{PST}$ = past $\mathrm{R}=$ Russian; $\mathrm{SEU}=$ Southeast Ukrainian; SG = singular; SWU = Southwest Ukrainian

\section{References}

Adelaar W.F.H. [with the collaboration of Pieter V. Muysken]. 2004. The languages of the Andes. Cambridge.

Alpatov V.M. 2006. Aktual'no li učenie Marra? - Voprosy jazykoznanija 1: 3-15.

Andersen H. 2006. Grammation, regrammation, and degrammation. Tense loss in Russian. - Diachronica 23.2: 231-258. 
Andersen H. 2009. Reduplication in Slavic and Baltic: Loss and renewal. - Morphology 19: 113-134.

Bauer B. 2000. Archaic syntax in Indo-European. Berlin, New York.

Bohas G. 2006. The organization of the lexicon in Arabic and other Semitic languages. Boudelaa S. (ed.). Perspectives on Arabic linguistics XVI. Amsterdam, Philadelphia: 1-37.

Bois J.W. du. 1987. The discourse basis of ergativity. - Language 63.4: 805-855.

Cerrón-Palomino R. 1987. Lingüística Quechua. Cuzco.

Comrie B. 2008. Inflectional morphology and language contact, with special reference to mixed languages. - Simund P., Kintana N. (eds.). Language contact and contact languages. Amsterdam: 15-32.

Danylenko A. 2000/1997. The genitive of agent and the instrumental of means in Old Ukrainian: An old idea worth revising? - General Linguistics 37.1: 41-70.

Danylenko A. 2003. Predykaty, vidminky i diatezy v ukrajins'kij movi: istoryčnyj i typolohičnyj aspekty. Kharkiv.

Danylenko A. 2005. Is there any possessive perfect in North Russian? - Word 56.3: 347-379.

Danylenko A. 2011. Linguistic and cultural border crossings in the Grand Duchy of Lithuania or, can the Grand Duchy of Lithuania be defined as a Sprachareal? - Petit D. (ed.). Langues baltiques, langues slaves. Paris: 141-173.

Danylenko A. 2012. Auxiliary clitics in Southwest Ukrainian: Questions of chronology, areal distribution, and grammaticalization. - Journal of Slavic Linguistics 20.1: 3-34.

Danylenko A. 2013. Ukrainian in the language map of Central Europe: Questions of arealtypological profiling. - Journal of Language Contact 6.1: 134-159.

Danylenko A. 2015. On the mechanisms of the grammaticalization of comitative and instrumental categories in Slavic. - Journal of Historical Linguistics 5.2: 267-296.

Dixon R.M.W. 1997. The rise and fall of languages. Cambridge.

Fenk-Oczlon G., Fenk A. 1999. Cognition, quantitative linguistics, and systemic typology. Linguistic Typology 3.2: 151-177.

Fenk-Oczlon G., Fenk A. 2008. Complexity trade-offs between the subsystems of language. Miestamo M., Sinnemäki K., Karlsson F. (eds.). Language complexity. Typology, contact, change. Amsterdam, Philadelphia: 43-65.

Gil D. 2008. How complex are isolating languages? - Miestamo M., Sinnemäki K., Karlsson F. (eds.). Language complexity. Typology, contact, change. Amsterdam, Philadelphia: 109-131.

Harris A., Campbell L. 1995. Historical syntax in cross-linguistic perspective. Cambridge.

Haspelmath M., Michaelis S.M. 2017. Analytic and synthetic: Typological change in varieties of European languages. - Buchstaller I., Siebenhaar B. (eds.). Language variation - European perspectives VI. [Selected papers from the 8th International Conference on Language Variation in Europe, Leipzig 2015]. Amsterdam: 1-17.

Haudricourt A.G. 1961. Richesse en phonèmes et richesse en locutions. - L'Homme. Revue française d'anthropologie 1.1: 5-10.

Heine B., Kuteva T. 2005. Language contact and grammatical change. Cambridge.

Heine B., Kuteva T. 2006. The changing languages of Europe. Oxford, New York.

Humboldt W. von. 1836. Über die Verschiedenheit des menschlichen Sprachbaues und ihren Einfluss auf die geistige Entwickelung des Menschengeschlechts. Berlin.

Kjamilev S.X., Mel'nikov G.P. 1983. Problema minimal'nyx smyslorazličitel'nyx i značaščix edinic v jazykax semitskogo stroja. - Voprosy jazykoznanija 5: 87-96.

Kusters Ch.W. 2000. Morphological simplification: More than erosion? - Gilbers D., Nerbonne J., Schaeken J. (eds.). Languages in contact. Amsterdam, Atlanta: 225-230.

Kusters Ch.W. 2003. Linguistic complexity. The influence of social change on verbal inflection. Utrecht. 
Kusters Ch.W. 2008. Complexity in linguistic theory, language learning and language change. - Miestamo M., Sinnemäki K, Karlsson F. (eds.). Language complexity: Typology, contact, change. Amsterdam: 3-22.

Lutin S.A. 1990. Sistemno-tipologičeskij analiz rezul'tativnyx konstrukcij russkix govorov Severa i Severo-Zapada. [Candidate of Science Dissertation; Peoples' Friendship University, Moscow].

Marr N.Ja. 1934. Aktual'nye problemy i očerednye zadači jafetičeskoj teorii. - Marr N.Ja. Izbrannye raboty. [vol. 3: Jazyk i obščestvo]. Moscow, Leningrad: 61-77.

Martinet A. 1979. Shunting on to ergative or accusative. - Plank F. (ed.). Ergativity. Toward a theory of grammatical relations. London: 39-43.

Maslov J.S. 1948. Vid i leksičeskoe značenie glagola v russkom jazyke. - Izvestija Akademii Nauk SSSR. Serija literatury i jazyka 7.4: 303-316.

McWhorter J.H. 2001. The world's simplest grammars are creole grammars. - Linguistic Typology 5.1: 125-166.

McWhorter J.H. 2008. Why does a language undress? - Miestamo M., Sinnemäki K., Karlsson F. (eds.). Language complexity. Typology, contact, change. Amsterdam, Philadelphia: 167-190.

Meillet A. 1922. Des innovations du verbe slave. - Revue des études slaves 22.1: 38-46.

Meillet A. 1924. Le slave commun. Paris.

Mel'nikov G.P. 1969. Jazykovaja stratifikacija i klassifikacija jazykov. - Edinicy raznyx urovnej jazyka i ix vzaimodejstvie. Moscow: 45-73.

Mel'nikov G.P. 1971. Determinanta - veduščaja grammatičeskaja tendencija jazyka. - Fonetika, fonologija, grammatika. [K semidesjatiletiju A.A. Reformatskogo]. Moscow: 359-367.

Mel'nikov G.P. 1973. Sistemnyj podxod v lingvistike. - Sistemnye issledovanija 1972. Moscow: 183-204.

Mel'nikov G. P. 1986. Sistemnaja lingvistika Gumbol'dta-Sreznevskogo-Potebni-Boduèna i sovremennaja sistemnaja tipologija jazykov. - Problemy tipologičeskoj, funkcional'noj i opisatel'noj lingvistiki. Moscow: 13-26.

Mel'nikov G.P. 1988a. Kommunikativnyj rakurs - osnova semantičeskogo i grammatičeskogo svoeobrazija jazyka kak izobrazitel'noj znakovoj sistemy. - Metodologija lingvistiki i aspekty izučenija jazyka. Moscow: 13-26.

Mel'nikov G.P. 1988b. Systemology and linguistic aspects of cybernetics. Amsterdam.

Mel'nikov G. P. 1997. Ketegorii stepeni dlitel'nosti glagol'nogo dejstvija i ee svjaz' s kategoriej vida. - Trudy aspektologičeskogo seminara filologičeskogo fakul'teta MGU im. M. V. Lomonosova. [vol. 1]. Moscow: 122-139.

Mel'nikov G.P. 2003. Sistemnaja tipologija jazykov. Moscow.

Miestamo M., Sinnemäki K., Karlsson F. (eds.). 2008. Language complexity. Typology, contact, change. Amsterdam, Philadelphia.

Milroy J., Milroy L. 1985. Linguistic change, social network and speaker. - Journal of Linguistics 21: 339-384.

Oksaar E. 1999. Social networks, communicative acts and the multilingual individual. Methodological issues in the field of language change. - Jahr E.H. (ed.). Language change: Advances in historical sociolinguistics. Berlin, New York: 3-19.

Orr R.A. 1999. Evolutionary biology and historical linguistics. - Diachronica 16.1: 123-157.

Plank F. 1986. Preface. - Folia Linguistics 20: 1-2.

Plank F. 1998. The co-variation of phonology with morphology and syntax: A hopeful history. - Linguistic Typology 2: 195-230.

Polikarpov A.A. 1989. Ėlementy teoretičeskoj sociolingvistiki. Moscow.

Potebnja A.A. 1941. Iz zapisok po russkoj grammatike. [vol. 4: Glagol. Mestoimenie. Čislitel'noe. Predlog]. Moscow, Leningrad. 
Rodionov V.A. 1989. “Cel'nosistemnaja tipologija” vs. “častnaja tipologija”. - Voprosy jazykoznanija 1: 16-30.

Sampson G., Gil D., Trudgill P. (eds.). 2009. Language complexity as an evolving variable. Oxford.

Schwegler A. 1990. Analyticity and syntheticity. A diachronic retrospective with special reference to Romance languages. Berlin, New York.

Sgall P. 1971. On the notion of 'type of language'. - Travaux linguistiques de Prague 4: Études de la phonologie, typologie et de la languistique generale. Prague: 75-87.

Silina V.B. 1982. Istorija kategorii glagol'nogo vida. - Avanesov R.I., Ivanov V.V. Istoričeskaja grammatika russkogo jazyka. Morfologija. Glagol. Moscow: 158-279.

Sinnemäki K. 2009. Complexity in core argument marking and population size. - Sampson G., Gil D., Trudgill P. (eds.). 2009. Language complexity as an evolving variable. Oxford: 126-140.

Skalička V. 1966. Ein “typologisches Konstrukt”. - Travaux linguistiques de Prague 2: Les problèmes du centre et de la périphérie du systemme de la langue. Prague: 157-166.

Sreznevskij I.I. 1887. Mysli ob istorii russkogo jazyka i drugix slavjanskix narečij. St. Petersburg.

Tambovtsev Yu. (rev.). 2005. Gennadij Prokop'evich Mel'nikov, Sistemnaja tipologija jazykov: Printsipy, metody, modeli. Moskva: Nauka, 2003. 395 pp. - Word 56.1: 139-147.

Tchekhoff C. 1978. Aux fondements de la syntaxe: l'ergatif. Paris.

Tchekhoff C. 1979. From ergative to accusative in Tongan: An example of synchronic dynamics. - Plank F. (ed.). Ergativity. Toward a theory of grammatical relations. London: 407-418.

Trudgill P. 1992. Dialect typology and social structure. - Jahr E.H. (ed.). Language contact: Theoretical and empirical studies. Berlin, New York: 195-211.

Trudgill P. 1996. Dialect typology: Isolation, social network and phonological structure. Guy G.R., Feagin C., Schiffrin D., Baugh J. (eds.). Towards a social science of language. [vol. 1: Variation and change in language and society]. Amsterdam, Philadelphia: 3-21.

Trudgill P. 1997. Typology and sociolinguistics: Linguistic structure, social structure and explanatory comparative dialectology. - Folia Linguistica 31.3/4: 349-360.

Trudgill P. 2010. Contact and sociolinguistic typology. - Hickey R. (ed.). The handbook of language contact. Malden (MA): 299-319.

Trudgill P. 2011. Sociolinguistic typology. Oxford.

Wahlström M. 2015. The loss of case inflection in Bulgarian and Macedonian. Helsinki.

Wright W. 1967. A grammar of the Arabic language. [2 vols.]. Cambridge.

Zubkova L.G. 1977. Segmentnaja organizacija slova. Moscow.

Zubkova L.G. 1989. Lingvističeskie učenija konca XVIII-načala XX v.: Razvitie obščej teorii jazyka $v$ sistemnyx koncepcijax. Moscow.

Zubkova L.G. 1990. Fonologičeskaja tipologija slova. Moscow.

Zubkova L.G. 2010. Princip znaka v sisteme jazyka. Moscow. 